\title{
DINAMIKA URBAN SUFISME DI INDONESIA: CONTINUITY AND CHANGE DALAM MAJELIS SHALAWAT MUHAMMAD DI SURABAYA
}

\author{
Rubaidi \\ Universitas Islam Negeri Sunan Ampel Surabaya, Indonesia \\ E-mail: rubaidi@uinsby.ac.id
}

\begin{abstract}
This paper discusses the phenomenon of urban sufism among the majelis Shalawat Muhammad under the murshid Gus Kahar in Surabaya with followers (disciples) spreading in various places especially East Java, even abroad. The theory of continuity and change is used to critically review Howell's concept on urban sufism, and to present key concepts on sufism in its generic sense in terms of doctrine and empirical praxis. Although based in Surabaya, the doctrine and praxis of urban sufism in the Majelis Shalawat Muhammad reflects generic sufi teachings. The findings of this research reveal that the principle of continuity and change prevails in sufi tradition from time to time. This finding is different from Howell's theory which stress on ritual dimension. The followers of Shalawat Muhammad emphasize more on education on the basis of praxis (säliksulük, riyädah, and mujähadah), in addition to the dimension of doctrine itself.
\end{abstract}

Keywords: Sufi education; Shalawat Muhammad; continuity and change; urban sufism.

\section{Pendahuluan}

Riset ini secara spesifik hendak mengkaji kembali dimensi sufisme, khususnya fenomena urban sufisme di kota-kota besar di Indonesia dan umumnya diikuti oleh lapisan kelas menengah perkotaan. Sufisme sebagai ruh atau inti dari ajaran Islam mulai mendapat antusiasme masyarakat perkotaan. Antusiasme dari masyarakat perkotaan terhadap sufisme oleh Steven J. Salm dan Eric Ross digambarkan sebagai "the part of their purpose was to reflect or express some part of a divine or cosmic reality". "Terlebih masyarakat Indonesia dalam

${ }^{1}$ Eric Ross, Sufi City: Urban Design and Archetypes in Touba (Rochester: University of Rochester Press, 2006), 56. 
konteks beragama dikenal memiliki keragaman yang luar biasa atas pengamatan dan interpretasi religius. ${ }^{2}$ Keragaman ini berdampak pada bentuk ekspresi antusiasme beragama (beribadah), mulai yang hanya mengambil spirit sufisme dalam bentuk zikir hingga pendidikan laku sälik melalui bimbingan murshid secara ketat. Bentuk ekspresi pertama seperti dikaji oleh Howell melalui gairah kelas menengah perkotaan yang diwakili oleh entitas kelompok neo-modernisme. Sebagian besar kelompok masyarakat perkotaan yang lain, tetap mengekspresikan gairah sufisme, baik secara akar kesejarahan maupun doktrin ajaran tetap berpijak kepada doktrin ajaran sufisme dari masa lalu, pendidikan sälik yang ketat. Secara kelembagaan, ekspresi gairah sufisme ini mengambil beberapa bentuk, seperti tarekat, majelis selawat, dan majelis zikir.

Fenomena urban sufism seperti deskripsi di atas jelas menarik perhatian secara akademis. Lebih-lebih melihat kegairahan spiritual yang diwakili oleh kelompok Muslim dari garis ideologi neo-modernis. Sepanjang sejarahnya, di Timur Tengah, ajaran sufisme yang terus dihujat sejak era pra revivalisme (abad ke-18) hingga revivalisme (abad ke-19 hingga 20), terus eksis hingga kini. Fenomena sama tidak jauh berbeda dengan di Indonesia. Di Sumatera Barat, gerakan Paderi abad ke-18, baik dipimpin oleh tiga haji (Haji Miskin, Sumanik, dan Piobang) maupun Imam Bonjol. ${ }^{3}$ Semenjak gerakan Paderi ini, kaum modernis terus melakukan penyerangan terhadap sufisme di berbagai daerah di Indonesia hingga abad ke-20.

Alih-alih mengalami kemunduran, ajaran sufisme dalam berbagai bentuknya terus bertahan dan berkembang sesuai dengan dimensi ruang dan waktu. Gerakan sufisme juga tidak hanya mengambil bentuk "tradisional" dan "konservatif", yakni tarekat. Tetapi, terdapat puluhan majelis zikir dan majelis shalawat. ${ }^{4}$ Menurut Howell, meskipun doktrin sufisme terus mendapat tantangan dari berbagai

2 Julian Millie, Greg Barton, Linda Hindasah and Mikihiro Moriyama, "PostAuthoritarian Diversity in Indonesia's State-Owned Mosques: A Manakiban Case Study", Journal of Southeast Asian Studies, Vol. 45, No. 2 (2014), 194-213.

3 Abd A'la, "Geneaologi Radikalisme Muslim Nusantara: Akar dan Karakteristik Pemikiran dan Gerakan Kaum Paderi dalam Perspektif Hubungan Agama dan Politik Kekuasaan", Pidato Ilmiah Pengukuhan Guru Besar dalam Bidang Ilmu Sejarah Pemikiran Politik Islam, IAIN Sunan Ampel Surabaya, 2008.

4 Arif Zamhari, "Socio-Structural Innovations in Indonesia's Urban Sufism: The Case Study of Majelis Zikir and Shalawat Nurul Mustofa," Journal of Indonesian Islam, Vol. 7, No. 1 (2013). 
kelompok pembaru, sufisme akan terus berkembang sesuai dengan perkembangan masyarakat Muslim, terutama dinamika perkembangan aspek sharīah (baca: fikih) dalam masyarakat Islam. ${ }^{5}$ Selain itu, masih menurut Howell, dinamika sufisme selalu berbanding lurus dengan dinamika perkembangan sosial masyarakat Islam dalam beradaptasi dengan nilai-nilai modernis di bidang ekonomi, politik, sosial, budaya, dan sebagainya. ${ }^{6}$

Menariknya, seperti dalam banyak tulisan Howell, kelompok yang dahulu menolak doktrin ajaran sufisme lambat laun menerimanya walau parsial. Disebut parsial, karena penerimaan mereka terhadap doktrin sufisme tidak seperti umumnya dalam tradisi keagamaan kaum tradisionalis yang menerima seluruh doktrin ajaran tanpa syarat. Kaum neo-modernis yang tumbuh subur di kota-kota besar seperti Jakarta, Bandung, Surabaya, dan seterusnya, oleh Howell disebutnya sebagai fenomena urban sufism. Dahulunya, kaum modernis menolak doktrin sufisme tanpa syarat. Tetapi, dalam perkembangan gerakan pembaruan Islam, mereka mulai mengakui eksistensi sufisme ini. Kekeringan spiritual yang tidak mampu dijawab oleh doktrin fikih maupun pemikiran Islam secara umum akhirnya dijawab oleh spiritualitas Islam, yakni sufisme. Namun, sayangnya, mereka tidak "memeluk" tradisi ajaran sufisme secara "total." Mereka tetap menolak beberapa hal kunci, seperti pengakuan terhadap murshid, mengikuti ajaran salah satu tokoh sufí, tradisi tawassul terhadap para murshid, baik masih hidup, lebih-lebih yang telah meninggal. Singkatnya, kelompok neo-modernis ini hanya mengambil penggalanpenggalan pemikiran maupun zikir kaum sufi yang dijadikan pegangan hidup mereka.

Artikel ini tidak membahas fenomena urban sufism yang direpresentasi melalui gairah spiritualitas oleh kelompok neomodernis, lebih-lebih mempertajam. Sebaliknya, tulisan ini berusaha menyajikan fenomena urban sufism yang direpresentasikan melalui Majelis Shalawat Muhammad dengan murshid Gus Kahar berbasis di kota Megapolitan, Surabaya. Seperti akan dilihat nanti, walaupun Majelis Shalawat Muhammad tumbuh berkembang di kota besar seperti Surabaya, tetapi sosok Gus Kahar sebagai murshid mendidik

${ }^{5}$ Julia D. Howell, "Sufism and The Indonesian Islamic Revival", The Journal of Asian Studies, Vol. 60, No. 3 (2001), 701-729.

6 Julia D. Howell, "Modernity and Islamic Spirituality in Indonesia's New Sufi Networks," dalam Martin van Bruinessen dan Julia D. Howell (eds.), Sufism and The Modern in Islam (New York and London: IB Tauris, 2007), 217. 
para muridnya tetap berpegang teguh pada prinsip-prinsip ajaran sufí secara kaku dan ketat, yakni sälik-sulük, mujähadah, muräqabah, dan seterusnya.

\section{Doktrin Pokok Ajaran Shalawat Muhammad}

Salah satu ciri pokok para tokoh sufi besar sepanjang masa adalah memiliki sistem pemikiran tentang ketuhanan dan kenabian (Allah dan Rasulullah). Ada kalanya pemikiran ini tertuang dalam banyak karya tertulis. Tetapi, banyak dijumpai para guru sufi tidak menulis pemikiran sufinya, melainkan para muridnya. Gus Kahar tidak banyak meninggalkan karya-karya tertulis. Cakrawala luas pemikiran Gus Kahar terdokumentasikan dalam ratusan rekaman, baik melalui handphone (HP), MP4, handycamp, maupun kaset VCD. Bahkan, beberapa pemikiran Gus Kahar sebagian kecil telah diunggah ke media YouTube dalam bentuk pengajian tasawuf di televisi. ${ }^{8}$

Jejak perilaku dan pemikiran sufi Gus Kahar tergambar dalam dua kitab awräd (kumpulan teks zikir) yang menjadi pegangan bagi para murid atau jemaah. Kedua kitab awräd ini menjadi amalan zikir dan wirid secara rutin bagi para jemaah. Selain dua kitab ini, Gus Kahar sebenarnya masih memiliki banyak amalan dalam bentuk zikir atau wirid yang diberikan kepada banyak individu para santri untuk menjadi pegangan amalan zikir secara individual setelah mendapat ijäza $b^{9}$ darinya. Kedua kitab itu adalah (1) Kitab Shalawat Muhammad dan (2) Kitab Shalawat 'Ażimìah.

Kitab kumpulan wirid pertama diberi nama Shalawat Muhammad Rahmatan li al-'Álamin. Kitab ini memiliki tujuh amalan zikir: (1) Zikir Qabharìab; (2) Surah Yāsīn; (3) Doa Kan₹ al-'Arsh; (4) Istighfär Rajab;

${ }^{8}$ Sebanyak 20 episode, pemikiran Gus Kahar pernah ditayangkan oleh TV9 dalam Program Kiswah "Kembang Tasawuf." Untuk melihat secara langsung pokok pemikiran Gus Kahar tentang hakikat makna Islam, dapat dilihat di YouTube dengan judul "Gus Kahar Kembang Tasawuf."

9 Istilah ijäala dalam tradisi pesantren yang lekat dengan tarekat dan sufisme berbeda dengan makna ijāah dalam pengertian umum. Ijāąa dalam makna ini merupakan pemberian suatu amalan zikir tertentu yang diberikan oleh seorang guru sufi terhadap salah seorang pengikutnya sesuai dengan kebutuhan pengikutnya. Seorang guru sufi tidak sembarangan memberi ijäah kepada seseorang. Dapat dipastikan, seorang guru sufi memberi ijäah amalan tertentu karena dirinya menjalankan bait-bait ijäah dimaksud dalam kehidupan sehari. Karena itu, saat ijäzah ini diberikan, maka ijäzah yang telah diamalkan ini memiliki banyak manfaat yang hanya dirasakan oleh seseorang yang diberi ijärab dengan mengamalkan ijäzah dimaksud. 
(5) Salawàt Muhammad; (6) Rātib al-Haddād; dan (7) Doa 'Akāshah. ${ }^{10}$ Ketujuh amalan zikir tersebut, sejak Gus Kahar menyebarkan ajaran Shalawat Muhammad kepada masyarakat umum sekitar 2004, selalu dibaca secara bersama-sama oleh para jemaah. Masing-masing amalan zikir ini memiliki langgam atau lagu sendiri-sendiri. Umumnya, para pembaca yang ditugaskan untuk membaca masing-masing amalan zikir adalah para santri senior atau seseorang yang secara khusus ditunjuk sendiri oleh Gus Kahar.

Dua di antara tujuh amalan zikir dalam ajaran Shalawat Muhammad memiliki nilai khusus, yaitu: (1) Zikir Qabharỹah dan (2) Shalawat Muhammad menjadi bagian inti dari kitab awräd Shalawat Muhammad, sekaligus doktrin inti ajaran Shalawat Muhammad yang disebar luaskan Gus Kahar. Amalan zikir Qabhärȳyah ${ }^{11}$ disusun sendiri oleh Gus Kahar. Sedangkan, amalan zikir Shalawat Muhammad adalah amalan zikir yang secara turun temurun diamalkan oleh para guru-guru sufi sepanjang masa secara sirr (rahasia) hingga pada diri Gus Kahar mendapat amanat dari para guru sufi untuk menyebarkan kepada khalayak umum.

Sementara itu amalan zikir Qabhärȳyah menurut penuturan Gus Kahar diajari sendiri oleh Allah dengan redaksi seperti apa adanya tanpa diubah sedikit pun. Sistem transmisi pengetahuan yang demikian ini terkadang tidak sesuai dengan kaidah bahasa Arab yang baik dan benar (naḥw-sarf). Di antara satu lafal di dalam zikir Qabhärȳah, yakni Ya Hayy, ${ }^{12}$ menurut tata bahasa (nabow-sarf) tidak sesuai. Tetapi, "gimana lagi, karena saya mendapatkan ajaran seperti

\footnotetext{
${ }^{10}$ Untuk melihat isi tujuh amalan zikir secara lengkap dapat dilihat pada: Gus Kahar, Kitab Shalawat Muhammad Rahmatan li al-'Alamin (t.t.: t.tp., 2010).

${ }^{11}$ Secara utuh, bait-bait amalan zikir Qabhärīyah berbunyi sebagai berikut: Ashbadu an là ilāh illa Allah wa ashhadu anna Muḥammad Rasūl Allah, Là ilāh illā Allah, Yà Allah, Yà Huwa, Yà Haqq, Yà Hayyi, Yà Qayyùm, Yà Qabhār, Yà Wabhāb, Yà Fattāh, Yà Wāhbid, Yà Aḥad, Yà Șamad. Lihat Ibid., 1.

12 Menurut kaidah Nahwu, lafal Yà Hayyi seharusnya dibaca Yä Hayyu. Namun, Gus Kahar menjelaskan, lafal Yà Hayyi bukan tidak ada maksudnya. Makna Yä Hayyi memiliki arti yang lebih dalam dibandingkan $Y \bar{a}$ Hayyu. Gus Kahar lantas menjelaskan, bahwa makna Yà Hayyi dimaksudkan agar kita memahami segala sesuatu (hakikat Allah), bukan hanya secara lahir (arti huruf saja), tetapi lebih memahami secara subtansi (hakikat). Gus Kahar menambahkan, ibarat melihat botol air mineral Aqua, seseorang tidak hanya menyebut Aqua atau paham Aqua saja. Lebih dari itu, seseorang selain menyebut Aqua juga tahu isi dan merasakan nikmatnya Aqua dimaksud. Gus Kahar, Wawancara, Sidoarjo 9 September 2015.
} 
itu dan tidak berani mengubahnya," jelas Gus Kahar. ${ }^{13}$ Lahirnya amalan zikir Qabhärìah, menurut Gus Kahar didapatkan setelah selama bertahun-tahun menjalani kehidupan sälik-sulük, zuhud, maupun riyädah. Zikir Qahhärȳy ini tidak ubahnya seperti gambaran panjang perjalanan sälik-sulük Gus Kahar dimanifestasikan ke dalam bait-bait zikir. Selain itu, zikir Qabhärỹah dapat dimaknai sebagai simbol perjalanan tingkat kemakrifatan Gus Kahar dalam perjalanan di dunia sufi. Karena itu, Gus Kahar sering menandaskan kepada para jemaah untuk selalu membaca zikir Qabhärȳyah dalam setiap kesempatan. Bukan hanya itu, selain mengamalkan zikir Shalawat Muhammad, Gus Kahar menetapkan zikir Qahbärȳyah ini kepada para muridnya sebagai zikir harian. Meskipun tidak memerinci sedemikian rupa, Gus Kahar berkali-kali mengingatkan kepada jemaah agar membaca zikir ini sebagai zikir harian karena besarnya barakah di dalamnya. "Bagi yang mau haji tetapi masih belum memiliki bekal, baca saja sebanyak-banyaknya zikir ini, maka nanti akan diajari oleh Allah ibadah haji yang hakikat," begitu Gus Kahar menyebut salah satu makna dibalik besarnya manfaat zikir Qabhärīyah. ${ }^{14}$

Kelima amalan zikir lainnya, yakni (1) Surah Yāsīn, (2) Doa Kanz al-'Arsh, (3) Istighfär Rajab, (4) Rätib al-Haddàd, dan (5) Doa 'Akāshah. Kelima alaman ini, di kalangan kiai dan habaib diketahui sejak lama memiliki banyak mazìyah atau keutamaan. Nilai-nilai keutamaan ini memiliki arti penting, khususnya untuk kepentingan masyarakat luas dalam maqam syariat dan tarekat. Menyebut di antara maziyah atau keutamaan ada pada doa Istighfär Rajab. Di dalam Kitab al-Majmū'ah alMubārakah fi Salawät al-Ma'thürah wa al-A'mäl al-Mabrürah, dijelaskan tentang mariyah atau keutamaan doa ini. Rasulullah bersabda, barang siapa membaca doa ini walaupun hanya sekali dalam seumur hidupnya, maka, Allah akan mengharamkan api neraka membakar orang tersebut. ${ }^{15}$ Mazìyah atau keutamaan seperti doa Istighfär Rajab

\footnotetext{
${ }^{13}$ Ibid.

14 Ibid.

15 Terdapat riwayat, suatu saat Rasulullah mendatangi salah seorang sahabat yang sedang meninggal. Pada saat orang tersebut meninggal, tidak seorangpun para tetangga datang untuk memakamkannya. Lalu Rasulullah memerintahkan beberapa sahabat untuk mengurus jenazah tersebut. Selesai dikuburkan, Rasulullah dan para sahabat mendatangi istri orang meninggal. Saat ditanya, amalan apa yang dikerjakan oleh sang suami selama hidupnya. Si istri menjawab, selama hidup suaminya tidak pernah berbuat kebaikan, melainkan selalu berbuat jahat pada sesama. Saat Rasulullah bertanya, tidak adakah sedikit amal ibadah yang diperbuat sang suami, si
} 
juga terdapat dalam doa atau zikir yang lainnya kiranya tidak perlu dijelaskan secara panjang lebar dalam tulisan ini.

Kitab Awräd kedua yang disusun Gus Kahar adalah Shalawat 'Ažimìyah yang dikemas dengan nama Zikir Mubārak Shaykbunā Kabar. Seperti dalam kitab awräd pertama, pada awräd kedua ini juga terdiri dari beberapa doa atau amalan zikir. Amalan zikir dalam awräd kedua meliputi: (1) Wasilab; (2) Burdah Shaykhunā Kahar, (3) Surah al-Mulk; (4) Zikir Yawmìah Shaykhunā Kahar, (5) Zikir Mubärak Shaykbunā Kahar; (6) Salawàt 'Az̧imìah; (7) Doa Ism al-A'zam; dan (8) Doa 'Ashürah.

Pada bagian pertama, yakni Wasilah, Gus Kahar mengetengahkan beberapa dalil al-Qur'ān yang menegaskan tentang arti penting wasilah. ${ }^{16}$ Sementara, Burdab Shaykhunā Kahar berisi tentang nyanyian yang ditulis dalam bahasa Arab yang menerangkan tentang kelebihan Gus Kahar sebagai murshid maupun guru (sufi) dari Shalawat Muhammad. Selain menerangkan tentang kelebihan Gus Kahar, burdah ini juga berisi doa untuk Gus Kahar sekaligus menjelaskan tentang arti penting peran para wali Allah dalam hubungannya dengan Rasulullah. ${ }^{17}$ Burdah ini disusun bukan secara tiba-tiba. Menariknya, burdah ini ditulis oleh habib Abdurrahman b. Ba'agil, Ampel, Surabaya. Pengakuan Ba'agil terhadap Gus Kahar diwujudkan dalam bentuk syair setelah sekian lama mengikuti pengajian Shalawat Muhammad dan sharing pemikiran bersamanya. "Gus Kahar bukan orang sembarangan. Ia adalah min jumlat al-khärij al-ādah," kata Ba'agil. ${ }^{18}$ Tingkat kedalaman pengetahuan Gus Kahar tentang dimensi

istri menjawab, bahwa, sang suami diketahui sering membaca doa istigfar Rajab. Lihat Muhammad Baban, al-Majmū'ah al-Mubärakah fi Salawät al-Ma'thürah wa alA'mäl al-Mabrürah (t.t.: t.tp., t.th.), 87.

16 Beberapa ayat al-Qur'ān terpenting yang menerangkan dan menegaskan tentang wasilah didasarkan pada empat ayat-ayat penting, yakni; (1) Surah al-Mā'idah [5]: 35, (2) Surah al-Isrā' [17]: 57, (3) Surah al-A'rāf [7]: 157, dan (4) Surah al-Ankabūt [29]: 69.

${ }_{17}$ Burdah Shaykhunā Kahar yang berisi syair, menariknya karena disusun oleh seorang habib yang tinggal di daerah Ampel, Surabaya. Habib ini bernama Abdurrahman b. Ba'agil yang pernah mengenyam pendidikan cukup lama dengan menyelesaikan S1 dan S2 di Timur Tengah. Lihat Gus Kahar, Dhiker al-Mubärak Shaykbunā Kahar (t.t.: t.tp., 2014), 7.

18 Dikutip dari pernyataan habib Abdurrahman b. Ba'agil dalam suatu pengajian Shalawat Muhammad di rumah H. Muhammad Sukri, Sentul Tanggulangin Sidoarjo, 22 Agustus 2015. 
tasawuf menyakinkan Ba'agil tentang kewalian Gus Kahar dalam bentuk syair dimaksud.

Seperti dalam kitab awräd Shalawat Muhammad, pada awräd kedua ini, terdapat dua zikir yang disusun sendiri oleh Gus Kahar, yakni (1) Zikir Yawmìyah Shaykhunā Kahar ${ }^{19}$ dan (2) Zikir Mubärak Shaykbunā Kahar. Terdapat perbedaan antara zikir pertama dan kedua. Pada Zikir Yawmìyah Shaykhunā Kahar merupakan susunan Gus Kahar secara keseluruhan. Tetapi, pada zikir Mubärak Shaykhunā Kabar, seperti dituturkan sendiri oleh Gus Kahar merupakan penyempurnaan dari zikir Mubārak, yang telah ada sebelumnya. ${ }^{20}$ Bahkan, menurut Gus Kahar, sesungguhnya, terdapat beberapa bait dari rangkaian zikir Mubārak yang tidak pernah diajarkan sebagai amalan zikir kepada banyak orang, melainkan hanya dibaca oleh orang-orang tertentu, alias kalangan khusus. ${ }^{21}$ Zikir kedua ini selain diamalkan serta dibaca oleh pengikut Shalawat Muhammad juga diamalkan oleh para santri maupun pengikut KH. Sahlan. Satu-satunya perbedaan antara pengikut Gus Kahar dengan pengikut Kiai Sahlan ada pada tambahan bait yang umumnya hanya dibaca oleh para santri Gus Kahar.

Selain surah al-Mulk, zikir Ism al-A'şam, dan doa 'Akäshah, dalam awräd kedua terdapat Shalawat 'Azamìah. Seperti zikir atau doa-doa dalam awräd pertama, zikir atau doa tersebut (dalam awräd kedua) menjadi bagian tidak terpisahkan selama ribuan tahun para wali Allah maupun para pengikut tarekat, lebih-lebih para murshid. Selain zikir yawmìyah Shaykhunā Kahar dan zikir Mubārak Shaykhunā Kahar sebagai

19 Bait-bait dalam zikir Yawmìyah Shaykhunā Kahar berbunyi sebagai berikut: Yā Qabhār, Mubìt Rabb al-Sayyidì Hasìb al-Fa'āl, Khalaq al-Khalq, al-Bāri' al-Musawwir, Yā

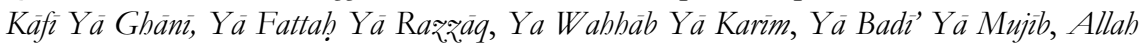
Jibril Wali Muhammad, Muhammad Wali Jibril tiga kali. Lihat Gus Kahar, Dhiker alMubārak Shaykhunā Kahar. 12.

20 Menurut penuturan Gus Kahar, zikir Mubārak ini disusun oleh Kiai Sahlan Sidorangu Sidoarjo. Kiai Sahlan dikenal sebagai salah seorang kiai dikenal oleh masyarakat sebagai salah seorang wali Allah. Kiai Sahlan memiliki Pesantren di Desa Sidorangu Krian Sidoarjo. Pesantren Kiai Sahlan hingga saat ini masih berdiri dan dikelola oleh para putra dan cucunya.

${ }^{21}$ Beberapa bait khusus dari rangkaian zikir Mubärak yang tidak pernah diajarkan secara umum, tetapi dibuka kembali lalu diajarkan kepada umum adalah sebagai berikut: Là Iläh illà Allah al-'Az̄ìm al-Halìm, Là Iläh illà Allah Rabb al-'Arsh al-'Az̄ìm, Là Ilāh illà Allah Rabb al-Samāwāt wa Rabb al-'Arḍ wa Rabb al-'Arsh al-Karìm. Là Ilāh illà Allah al-Halìm al-Karìm, Là Ilāh illā Allah Rabb al-'Arsh al-'Ažìn, Là Ilāh illā Allah Rabb al-Samāwàt wa Rabb al-'Ard wa Rabb al-Arsh al-Karim. Lihat Kahar, Dhiker alMubārak, 13. 
inti dari awrād kedua, juga Shalawat 'Ażimìyah sebagai inti dari awrād kedua ini. Gus Kahar mendapat ijärah Salawàt 'Ažimìyah langsung dari sang pembuat. Shalawat 'Ax̧imiyah ini disusun oleh habib Ahmad b. Idris, pendiri dari tarekat al-Idrīsìyah. Meskipun Gus Kahar tidak pernah menjelaskan secara langsung, namun dalam tradisi tasawuf, transmisi atau ijäzah melalui para murshid yang telah meninggal adalah suatu kelaziman. Selain itu, dalam suatu kesempatan pengajian, Gus Kahar pernah menjelaskan secara panjang lebar tentang sosok al-Idris sebagai pewaris Shalawat 'Ax̧imìah ini.

\section{Shalawat Muhammad dan Muslim Kelas Menengah Perkotaan}

Fenomena urban sufism, baik dalam Majelis Shalawat Muhammad atau Majelis Zikir di kota-kota besar di Indonesia, sebenarnya bukan fenomena baru. Fenomena yang kurang lebih sama telah lahir pada masyarakat kota Baghdad di era Islam klasik, yakni di era dinasti 'Abbāsìyah. Kota Baghdad pernah tumbuh menjadi kota yang tidak ubahnya sebagai kota kosmopolitan seperti saat ini. Pada masa pemerintahan dinasti tersebut, kota ini mengalami masa pertumbuhan urban sufism melalui para guru sufi besar, ${ }^{22}$ seperti Ḥasan al-Bașrī, Dhū al-Nūn al-Miṣrī, dan Abū Manșūr al-Hallāj yang pernah menjadi pusat perhatian masyarakat Muslim karena ajaran dan doktrin tasawuf mereka. Kegairahan kembali terhadap ajaran sufisme karena keinginan untuk mendapatkan (kembali) ajaran Islam yang bersifat esoteris yang diyakini sebagai inti dari ajaran Islam itu sendiri.

Faktor utama tumbuh berkembangnya ajaran sufisme yang dimotori oleh para sufi besar didahului oleh fenomena "modernisasi" masyarakat Islam waktu itu. Wilayah Islam yang membentang luas, selain di Timur Tengah juga terbentang mencakup Afrika Utara hingga Spanyol atau kawasan Eropa Barat. Orientasi hukum menjadi dominan. Karena sifatnya yang berkaitan erat dengan kekuasaan, maka, ilmu fikih telah menarik minat banyak cendekiawan yang umumnya berambisi mengejar karir di pemerintahan. Banyak ulama yang identik dengan fuqahä'. Sesuai dengan wataknya, hukum selalu bersifat "eksoteris," yakni menekankan aspek lahiriah. ${ }^{23}$ Hanya saja saat itu belum muncul istilah urban sufism seperti istilah yang

${ }^{22}$ Gusti Abdul Muis, "Menyimak Tasawuf Sunni”, Jurnal Pesantren, Vol. 2, No. 3 (1985), 19.

${ }^{23}$ Nurcholis Madjid, "Tasawuf sebagai Inti Keberagamaan” Jurnal Pesantren, Vol. 2, No. 3 (1985), 3. 
digunakan Howell yang menandai fenomena lahirnya gairah "spiritualitas" baru di kalangan masyarakat perkotaan. ${ }^{24}$ Istilah Urban Sufism dipopulerkan oleh Howell dengan merujuk kepada lahirnya beberapa majelis taklim maupun kajian-kajian di Jakarta, seperti Paramadina, Tazkiya Sejati, ICNIS, IIMAN, dan lain sebagainya. Dalam perkembangannya, istilah ini tambah semarak dengan lahirnya tokoh-tokoh seperti ustaz Haryono, Arifin Ilham, Aa Gym, dan seterusnya dengan majelis taklim dan zikir. Bahkan, belakangan juga tumbuh subur berbagai majelis zikir maupun majelis shalawat yang umumnya dirintis oleh para habib. Fenomena inilah yang melandasi lahirnya term urban sufism dimaksud. Dalam perkembangannya, fenomena urban sufism tidak bisa dipisahkan dengan gerakan tasawuf konvensional yang terikat dengan simpul-simpul organisasi tarekat seperti Tarekat Qādirīyah wa Naqshabandāyah (TQN), Shādhilīyah, Shattarīyah, dan masih banyak lagi. Di sekitar Jakarta saja, tidak kurang dari 158 tempat manakiban yang berafiliasi kepada tarekat konvensional ini. ${ }^{25}$

Penggunaan istilah urban sufism secara konseptual diambil dalam konteks mengkerangkai berbagai gerakan spiritual yang mengambil inti-inti ajaran tasawuf. Beberapa inti ajaran tasawuf dimaksud, seperti dimaksud oleh Howell maupun Fathurahman, mencakup konsep kunci seperti zikir, doa, dan pembersihan hati (tabdhib al-Nafs). ${ }^{26}$ Secara genealogis, lahirnya gerakan urban sufism sebagai keberlanjutan gerakan neo-sufisme yang lahir sebagai kritik atas sufisme awal. Neosufisme, menurut Fathurahman, ciri utamanya adalah upaya menyandingkan antara ajaran sharīah dengan tasawuf itu sendiri. Dasar-dasar gerakan neo-sufisme ini merujuk kepada nama-nama tokoh seperti al-Ghazālī dan al-Qushayrī dalam melakukan reformulasi ajaran tasawuf. Menurut Azra, sejak abad ke-17 hingga seterusnya, proses islamisasi di berbagai dunia Islam, termasuk di

\footnotetext{
${ }^{24}$ Baca kembali beberapa karya Howell. Lihat Arif Zamhari dan Julia D. Howell, "Taking Sufism to The Streets: Majelis Zikir and Majelis Salawat as New Venues for Popular Islamic Piety in Indonesia", Review of Indonesian and Malaysian Affairs, Vol. 46, No. 2 (2013); Julia D. Howell, "Repackaging Sufism in Urban Indonesia", ISIM Review, Vol. 19/Spring (2007).

25 Oman Fathurahman, "Urban Sufism: Perubahan dan Kesinambungan Ajaran Tasawuf', dalam Rizal Sukma dan Clara Joewono (eds.), Gerakan dan Pemikiran Islam Indonesia Kontemporer (Jakarta: CSIS, 2007), 123-128.

${ }^{26}$ Ibid.
} 
Indonesia mencerminkan gerakan neo-sufisme ini. ${ }^{27}$ Gerakan ini selain bertujuan untuk mengharmoniskan hubungan antara dimensi sharí'ah dan tasawuf, sekaligus menentang berbagai paham atau ajaran tasawuf yang dipandang berbahaya. Beberapa konsep kunci tasawuf awal yang menjadi sasaran kritik dari gerakan neo-sufisme ini adalah konsep-konsep kunci dalam tasawuf seperti waḥdat al-wujüd, waḥdat aladyān, al-ittiḩäd atau bulül. Konsep-konsep ini, dalam pandangan kaum neo-sufis, selain bertolak belakang dengan ajaran shari'ah, juga cenderung meninggalkan ibadah kunci dalam sharíah seperti salat. Karena itu, tarekat Shattarìyah misalnya, walaupun tidak ubahnya seperti tarekat konvensional lainnya, sejak awal menyatakan ketidaksetujuannya dengan ajaran seperti wahdat al-wujüd dan seterusnya. ${ }^{28}$

Di sinilah letak perbedaan antara urban sufism dalam pandangan Howell dalam pengertian neo-modernis dengan pandangan mainstream yang umumnya diwakili oleh kaum tradisionalis. Terlepas dari penolakan terhadap ajaran ittiḥäd, ḥulül, waḥdat al-wujüd, waḥdat al-adyān, dan seterusnya, terdapat konsep kunci seperti penerimaan terhadap murshid, ketaatan total murid terhadap murshid, tawassul, dan masih banyak lagi. Konsep-konsep kunci ini tidak dijalankan oleh kelompok neo-sufis, persisnya neo-modernis seperti dalam studi Howell yang disebut sebagai kelompok urban sufism.

Dalam tradisi tasawuf sesungguhnya, sistem pendidikan yang berat, bahkan sulit dinalar dengan akal sehat akhirnya melahirkan guru-guru tasawuf secara berkesinambungan serta memiliki hubungan keilmuan dari tokoh sufi generasi awal hingga saat ini. Sosok al-Junayd atau al-jili misalnya, secara keilmuan keduanya tidak lain adalah para murid dari al-jīlānī. Gambaran seperti ini akan menjelaskan terhadap setiap guru sufi, baik periode awal sampai guru-guru tasawuf di Indonesia sekalipun. Fenomena ini pula yang dapat menjelaskan, mengapa Hamzah Fansuri, Syamsuddin al-Sumaterani, Abdul Jalil atau lebih populer dengan nama Siti Jenar mewarisi ilmu Ibn 'Arabī maupun al-Hallāj, Jawabannya ada pada sistem pendidikan di dunia tasawuf yang tidak banyak dikaji oleh para peneliti. Setidaknya, deskripsi ini juga akan menjadi benang merah studi ini. Studi tentang Shalawat Muhammad yang direpresentasikan melalui figur Gus Kahar

27 Azyumardi Azra, Jaringan Ulama Timur Tengab dan Kepulauan Nusantara Abad XVII dan XVIII (Bandung: Mizan, 1994), 78.

${ }^{28}$ Fathurahman, Urban Sufism, 134. 
mewakili secara baik sistem pendidikan dalam dunia sufisme. Karena itu, meski kajian ini termasuk dalam kajian urban sufism, tetapi makna urban sufism dimaksud tidak sepenuhnya sama seperti makna urban sufism dalam perspektif Howell.

Berpusat di Surabaya dan Sidoarjo, Majelis Shalawat Muhammad memiliki pengikut ribuan. Para murid tersebar di Surabaya, Sidoarjo, Gresik, Lamongan, dan Mojokerto. Dalam perkembangan selanjutnya, para murid merambah ke berbagai daerah di Jawa Timur, bahkan, Jawa Tengah, Jakarta, Jawa Barat, hingga Kalimantan, Nusa Tenggara. Bahkan, jemaah ini sebagiannya berdomisi di luar negeri seperti Singapura, Malasyia, dan China. Baik secara strata sosial dan ekonomi, jemaah Shalawat Muhammad mencerminkan lapisan Muslim kelas menengah perkotaan. ${ }^{29}$ Secara profesi, jemaah memiliki beragam latar belakang seperti: (1) Pengusaha; (2) TNI/Polri; (3) PNS (birokrasi pemerintah, dosen, maupun guru); (4) Wiraswasta; (5) Jaksa; (6) BUMN/BUMD; (7) Pegawai (swasta) kantoran; dan sebagainya. Secara pendidikan, mereka memiliki latar pendidikan, mulai dari SMU, S1, S2, S3, bahkan terdapat beberapa profesor yang intensif mengikuti berbagai Majelis Shalawat Muhammad.

Tidak sedikit para murid Gus Kahar sebelumnya pernah menjadi pengikut di beberapa tarekat, seperti tarekat Qādirīyah wa Naqshabandīyah (TQN), Shādhilīyah, dan Wahidiyah. Kiai Abdul Rojak misalnya, sebelum aktif mengikuti Majelis Pengajian Shalawat Muhammad kurang lebih 10 tahun, sebelumnya aktif dalam Tarekat Qādirīyah wa Naqshabandīyah (TQN) di bawah murshid KH. Mustain Romli, Peterongan, Jombang. ${ }^{30}$ Meskipun tidak selama Rojak, Sururi yang telah menjadi pengikut Gus Kahar sekitar tiga tahun, dahulunya pernah aktif di dalam Tarekat Wahidiyah di bawah murshid KH. Abdul Majid dari Kedonglo Kediri. ${ }^{31}$ Kiai Rojak sebagai petani tebu yang sukses dan Sururi bekerja sebagai seorang pengembang perumahan, keduanya menempatkan Gus Kahar sebagai guru atau murshid dalam arti sesungguhnya karena belum pernah menjumpai seorang guru yang dapat membimbing secara rohani seperti dirinya.

\footnotetext{
29 Antara kurun waktu akhir Agustus, September, dan Oktober 2015, peneliti terlibat secara partisipatoris dalam berbagai pengajian Shalawat Muhammad di berbagai rumah para jemaah. Dalam durasi sekitar dua bulan saja, peneliti secara partisipatif telah mengikuti tidak kurang dari 10 pengajian yang didatangi sendiri oleh Gus Kahar sebagai murshid Shalawat Muhammad.

${ }^{30}$ Abdul Rojak, Wawancara, Surabaya 18 September 2015.

${ }^{31}$ Muhammad Sururi, Wawancara, Surabaya 18 September 2015.
} 
Terdapat beberapa murid Gus Kahar memiliki latar belakang dari ormas modernis seperti Muhammadiyah, bahkan organisasi Islam transnasional seperti HTI. Rofi'i telah menjadi murid Gus Kahar sekitar 10 tahun. Rofi'i pernah menjabat direktur Yayasan Pendidikan Indonesia-Amerika (YPIA) Cabang Surabaya. Selain dididik dalam tradisi intelektual kaum modernis, dirinya mengaku memiliki pandangan negatif terhadap para kiai. "Sebelum ikut Gus (baca: Gus Kahar), saya selalu berfikir negatif terhadap setiap kiai. Saya dahulu juga benci terhadap Gus Dur," Ungkap Rofi'i. ${ }^{32}$ Menurutnya, selama hidup bersama Gus Kahar dirinya diajari untuk mengamalkan berbagai wirid amalan hingga dirinya berjumpa, baik dalam mimpi maupun sadar dengan para guru sufi yang dijelaskan Gus Kahar. Dengan kadar berbeda, Saiful Amin, seorang manajer di salah satu perusahan multinasional di Gresik yang dididik dalam tradisi modernis juga memiliki pengalaman spiritual selama aktif dalam Majelis Shalawat Muhammad. Amin yang dididik dalam tradisi intelektual modernis yang mengedepankan rasionalisme merasa heran terhadap Gus Kahar yang mampu menjawab dan menjabarkan dimensi keislamaan secara mendalam, bahkan, di luar bingkai pemikiran para intelektual Muslim pada umumnya. ${ }^{33}$

Fenomena pengajian Majelis Shalawat Muhammad selalu mengundang perhatian masyarakat umum. Persepsi masyarakat di luar jemaah Shalawat Muhammad terhadap setiap penyelenggaran Majelis Shalawat ini memberi kesan "wah," "elite," "pesta," atau kesan-kesan "glamor" lainnya. Setiap pengajian Majelis Shalawat Muhammad selalu diiringi dengan konvoi kendaraan roda empat. Ratusan jemaah yang datang dari berbagai daerah datang ke tempat pengajian secara konvoi mengiringi mobil pribadi Gus Kahar berada diurutan kedua. Di depan Gus Kahar adalah mobil berfungsi sebagai patrol yang mengawal sang murshid. Di belakang Gus Kahar terdapat puluhan mobil dari berbagai merek. Mobil mewah hingga menengah seperti Mercedes Benz, Rubicon, BMW, Mini Cooper, Vellfire, Alphard, Pajero, CRV, New Xtrail, hingga Innova berkonvoi menuju kediaman tuan rumah. Pemandangan ini jelas-jelas memberi kesan tentang Gus Kahar maupun jemaah Majelis Pengajian Shalawat Muhammad identik dengan simbol kelas menengah perkotaan.

\footnotetext{
32 Muhammad, Wawancara, Surabaya 18 September 2015.

${ }^{33}$ Saiful Amin, Wawancara, Surabaya 18 September 2015.
} 
Di luar "dinas" pengajian rutin, Gus Kahar bersama beberapa muridnya tidak segan-segan menghabiskan waktu di kafe atau di pusat perbelanjaan modern atau mal di Surabaya. Di pusat perbelanjaan itu, rombongan Gus Kahar selalu menjadi pusat perhatian pengunjung lain. Gus Kahar selalu hadir bersama sejumlah murid. Kemanapun melangkah, Gus Kahar selalu dikelilingi para murid itu. Gus Kahar selalu mengajak orang-orang terdekat dalam jumlah banyak, antara 10 hingga 20 orang. Menariknya, ratusan bahkan ribuan murid Gus Kahar sekali, dua kali atau berkali-kali, pernah diajak bertemu di malmal yang tersebar di Surabaya seperti Tunjungan Plaza (TP), Ciputra World (CW), Pakuwon Trade Center (PTC), Grand City, Galaxy, dan mal besar lain yang menjadi ikon kelas menengah-atas di Surabaya.

Gaya hidup (life style) Gus Kahar bersama para muridnya menggambarkan suatu komunitas Muslim perkotaan kelas menengah, bahkan kelas atas. Sering kali rombongan besar Gus Kahar menjadi pusat perhatian pengunjung lain di mal-mal tersebut. Walaupun cara berbusana tidak menunjukkan simbol pakaian Muslim (baju takwa, surban, kopiah, dan seterusnya), tetapi, kesan Gus Kahar dan para santrinya sebagai suatu komunitas Muslim perkotaan tetap nampak jelas. Gaya bertutur, penampilan, bahkan pada saat menikmati makan minum di antara deretan kafe tidak luput dari perhatian para pengunjung yang kebetulan berada di samping rombongan ini. ${ }^{34}$ Bahkan, karena intensitas ke mal-mal yang begitu tinggi, hingga beberapa penjaga stan produk branded seperti Hugo Boss, Tonino Lamborghini, Rohul, Lacoste, atau kafe-kafe di dalam mal ini akrab dengan Gus Kahar maupun para santri. "Silakan Pak Kahar, ini ada motif baru yang datang dari Jakarta kemarin," sapa penjaga stan kepada Gus Kahar dan rombongannya. "Mohon maaf, Pak Kahar ini ternyata seorang kiai ya," kata salah seorang penjaga counter di Tonino Lamborghini spontan. "Ah, ndak kok," jawab Gus Kahar sekenanya. "Iya kok. Beberapa waktu kemaren, saya melihat Pak

\footnotetext{
34 Dengan memanfaatkan teknik shadowing yang banyak digunakan dalam riset akhirakhir ini, peneliti beberapa kali berkesempatan mengikuti pertemuan-pertemuan Gus Kahar bersama para muridnya di pusat-pusat perbelanjaan ini. Sosok Gus Kahar, meskipun tidak memakai busana Muslim pada umumnya, tetapi, kesan kuat kalau dirinya bersama para muridnya adalah komunitas santri perkotaan sangat nampak sekali. Hal ini nampak pada sistem simbol seperti dijelaskan di atas.

35 Berdasarkan kegiatan partisipatif dan shadowing (pengintaian) yang dilakukan peneliti mengikuti rombongan Gus Kahar di Mal Ciputra World Surabaya tanggal 2 September 2015.
} 
Kahar ceramah di TV9. Wajahnya mirip Pak Kahar. Iya itu Pak Kahar," sambung penjaga stan setengah menyelidik dan minta penegasan. ${ }^{36}$

Pada saat kongko di mal Ciputra World (CW) Surabaya, terdapat peristiwa menarik. Setelah keliling melihat mode di beberapa merek atau brand terkenal, Gus Kahar bersama para santrinya singgah di kafe Kopi Luwak. Sambil menikmati kopi lwwak, salah seorang murid Gus Kahar membuka laptop sembari menayangkan hasil suntingan program kembang tasawuf yang ditayangkan secara reguler di TV9 yang diasuh sendiri oleh Gus Kahar. ${ }^{37}$ Di tengah Gus Kahar menyimak hasil suntingan sebelum ditayangkan TV9, tiba-tiba datang seorang lelaki Tionghoa menyapa Gus Kahar. "Pak Kahar lagi di sini," sapa orang tersebut. "Iya ini bang lagi lihat video anak-anak," jawab Gus Kahar singkat. Sambil ikut melihat tayangan hasil suntingan, orang tersebut mengatakan, "hebat ya, Pak Kahar ini ternyata seorang kiai," sambungnya. "Ah enggak bang," jawab Gus Kahar menghindar. "Iya, saya pernah melihat di TV9 tayangan pengajian, ya persis seperti ini," jawab orang tadi sembari menunjuk pada video yang dilihat bersama-sama di laptop. ${ }^{38}$

Kebiasaan Gus Kahar yang sering bepergian ke berbagai mal-mal ini bukan tanpa maksud. Pada saat minum kopi sehabis keliling mal, Gus Kahar selalu memberi wejangan (nasihat) tentang berbagai dimensi hakikat Allah dan Rasulullah, juga mengupas dimensi ajaran sufisme. Selain itu, para murid yang diajak menemaninya, Gus Kahar selalu mengarahkan sisi kehidupan mereka secara halus. Pada saat Gus Kahar mengupas berbagai hal tentang dimensi tasawuf, terlihat para pengunjung yang duduk di pinggirnya ikut merekam pembicaraan ini. Beberapa pelayan yang hilir mudik melayani berbagai pesanan tidak luput mendengarkan pembicaraan meskipun sepotong-sepotong. Gus Kahar yang sering berkunjung di berbagai mal bukan tanpa tujuan.

\footnotetext{
36 Data ini diambil masih dari keiikutsertaan peneliti bersama rombongan Gus Kahar di Mal Ciputra World, Surabaya, 6 September 2015.

37 Sejak Mei 2015, Gus Kahar diminta mengisi program khusus TV9 di Surabaya tentang tasawuf. Acara ini bertitel "Kiswah Kembang Tasawuf." Sebelum wafat, Gus Kahar sempat mengisi program ini sebanyak 16 episode. Program ini juga dapat diakses melalui YouTube.

${ }^{38}$ Gus Kahar menjelaskan, seseorang yang bertemu di Mal Ciputra World itu adalah seseorang pendeta Katholik yang tinggal di satu perumahan elit di kawasan Pakuwon Surabaya. Data ini diambil masih dari keiikutsertaan peneliti bersama rombongan Gus Kahar di Mal Ciputra World Surabaya, 6 September 2015.
} 
Selain secara diam-diam berdakwah, Gus Kahar juga mendoakan terhadap mereka yang lalu lalang di pusat berbelanjaan ini agar selalu diberi rahmat oleh Allah. "Kita selalu mendoakan kepada mereka yang datang dan pergi ini, semoga selalu diberi kebahagiaan oleh Allah," tandasnya. Sisi lain dakwah Gus Kahar seperti ini mengingatkan kepada sosok Gus Miek (KH. Khamim Djazuli, Ploso, Kediri) yang sering sering kongkow di berbagai tempat hiburan malam, bahkan di tempat-tempat prostitusi yang tersebar di Surabaya.

Di berbagai mal tersebut, Gus Kahar sering berjumpa dengan para tamu dari berbagai strata sosial, seperti pejabat pemerintah, pengusaha, militer, jaksa, selain para murid yang dekat. Suatu saat, penulis berkesempatan mendampingi Gus Kahar bertemu dengan salah seorang pejabat tinggi pusat yang menduduki jabatan sebagai kepala di salah satu jabatan setara dengan menteri. Jenderal berbintang dua sengaja bertemu dengan Gus Kahar setelah bercerita, bahwa dirinya sejak lama mengenal baik Gus Miek dan sering bertemu di salah satu hotel berbintang di Surabaya. ${ }^{39}$ Selain itu, beberapa kali, peneliti pernah mendampingi pertemuan Gus Kahar dengan salah seorang pejabat pemerintah propinsi Jawa Timur, baik di Tunjungan Plaza (TP), Surabaya, maupun di Mal Lenmarc, Surabaya Barat. ${ }^{40}$ Pada pertemuan dengan jenderal, Gus Kahar banyak mengupas tentang peran seseorang yang memiliki kekuasaan untuk kepentingan masyarakat banyak. Dibanding dengan orang biasa, untuk menjadi kekasih Allah, seseorang yang memiliki jabatan akan lebih cepat untuk sampai (wusūit) kepada Allah dan Rasulullah. Sang jenderal sempat berdiskusi dengan Gus Kahar mengenai topik hakikat salat. Gus Kahar menandaskan, "selain salat fardu, salat anda itu ya memberi kebijaksaan kepada anak buah anda. Itu salat seorang jenderal," kata Gus Kahar. Berbuat baik, membuat kebijakan yang mengayomi orang banyak, dalam pandangan Gus Kahar adalah bentuk lain dari makna ibadah salat.

Banyak jemaah Majelis Shalawat Muhammad dijaring di mal-mal. Salah seorang di antaranya adalah Jodi. Sebelum aktif mengikuti pengajian Shalawat Muhammad, Jodi bekerja sebagai manajer Kafe

\footnotetext{
${ }^{39}$ Direkam dari dialog Gus Kahar dengan Jenderal berbintang dua di Ciputra World (CW) Mall, Surabaya, pada pertengahan Mei 2015.

40 Beberapa kali, peneliti juga berkesempatan mendampingi pertemuan Gus Kahar dengan seorang pejabat tinggi pemerintah propinsi Jawa Timur, antara bulan September-Oktober 2015.
} 
Rollas milik PTPN XII. Dirinya mengaku mengenal Gus Kahar karena sering minum kopi di gerai Kafe Rollas Tunjungan Plaza, Surabaya. Pada awalnya, Jodi sering mendapat tips dari Gus Kahar yang besaran tipsnya berbeda dibanding para pengunjung lain. Sebagai manajer, Jodi terlihat mondar-mandir untuk mengawasi anak buahnya dalam melayani para tamu. Sebagai manajer yang memperhatikan para pengunjung, Jodi menguping pembicaraan Gus Kahar bersama para muridnya. Tingkat keseringan Gus Kahar di Kafe Rollas yang selalu membahas berbagai dimensi tauhid secara diam-diam menarik perhatian Jodi. Pada akhirnya Jodi memberanikan diri bertanya kepada Gus Kahar, "Bapak kiai ya," ungkapnya menyidik. "Enggak, saya orang biasa," jawab Gus Kahar singkat. Suatu saat, Jodi mengaku bermimpi bertemu dengan Gus Kahar. Pada suatu kesempatan, Gus Kahar sendiri yang menawari kepada sambil berkata, "Saya tunggu kamu di rumah Puri," kata Gus Kahar yang kebetulan kediaman Gus Kahar di Perum Puri Indah Blok. AG No. 12 Sidoarjo yang menjadi salah satu pusat Majelis Pengajian Shalawat Muhammad tidak jauh dari rumah Jodi. ${ }^{41}$ Sejak pertemuan Jodi dengan Gus Kahar di kediaman Puri, Sidoarjo, meyakinkan dirinya untuk mengikuti Majelis Pengajian Shalawat Muhammad.

Berbeda dengan praktik ritual urban sufism seperti fenomena di Jakarta dalam gambaran Howell yang longgar dan tidak ketat, fenomena sebaliknya justru terjadi bagi jemaah Shalawat Muhammad. Gus Kahar menerapkan ajaran tasawuf sangat ketat, terutama bagi para murid khusus dalam lingkaran inti. Di manapun terdapat pengajian Shalawat Muhammad, para murid selalu hadir mengiringi Gus Kahar. Pendidikan Gus Kahar berbeda antara satu murid dengan murid lainnya. Singkatnya, model pendidikan yang dijalani oleh para murid tidak ada bedanya dalam tradisi sälik-sulük sebagaimana bertahun-tahun dijalankan oleh Gus Kahar. Singkatnya, pendidikan tasawuf yang diajarkan Gus Kahar pada para murid mencakup dimensi lahir dan batin yang sangat ketat.

Term urban sufism pada Howell, Fathurahman maupun peneliti lainnya kurang bisa mewakili dalam memotret ajaran tasawuf Gus Kahar dalam Majelis Shalawat Muhammad. Titik persinggungan term urban sufism untuk memotret pendidikan tasawuf Gus Kahar ada pada beberapa hal, pertama, dilihat dari para pengikutnya, jemaah Shalawat

\footnotetext{
${ }^{41}$ Jodi (Manager Cafe Rollas Tunjungan Plaza (TP) Surabaya), Wawancara, Surabaya 18 September 2015.
} 
Muhammad mencerminkan kelas menengah perkotaan dengan beragam latar belakang pendidikan, karir, maupun profesi. Kedua, seperti fenomena masyarakat urban lainnya di kota-kota besar Indonesia, jemaah Shalawat Muhammad adalah sekumpulan orangorang yang mengalami kegersangan spiritual dan ketidak puasan terhadap berbagai doktrin Islam yang ditawarkan oleh berbagai majelis taklim maupun berbagai siraman rohani baik di media televisi maupun para ustaz dan dai. Ketiga, sama dengan urban sufism lainnya, pada Majelis Pengajian Shalawat Muhammad juga menekankan ritual zikir dan amalan tasawuf lainnya.

Di luar konteks persamaan dengan term urban sufism, pada saat masuk secara mendalam ke dalam Majelis Pengajian Shalawat Muhammad akan dijumpai nuansa yang berbeda seperti umumnya fenomena urban sufism. Beberapa titik perbedaan dimaksud antara lain: Pertama, mengenal sosok Gus Kahar secara dekat akan mengerti dan memahami siapa sesungguhnya murshid Shalawat Muhammad ini. Sosok Gus Kahar yang lahir dan dibesarkan dalam tradisi sälik-sulūke. seperti halnya pendidikan sufisme yang mewakili genre sufisme seperti guru-guru sufi periode awal membentuk keluhuran budi pekerti. Singkatnya, sosok Gus Kahar memiliki aura (baca: nür) yang benarbenar menghipnotis para pengikutnya. Kedua, secara keilmuan, meskipun Gus Kahar sama sekali tidak dididik dalam pendidikan formal (kecuali hanya tingkat SMU), tetapi memiliki kedalaman pengetahuan tentang hakikat seperti tanpa batas. Gus Kahar banyak mengurai dan menjelaskan esensi berbagai kitab-kitab tasawuf klasik karya guru-guru besar tasawuf tanpa membaca. ${ }^{42}$ Karya-karya besar di bidang sufisme dari tokoh seperti al-Jjilānī, Ibn 'Arabī, al-Jîlī, al-Rūmī, al-Ghazāầ, Ibn 'Atā' Allah, dan masih banyak lagi dikupas secara detail. Bahkan, Gus Kahar masih memberi konsep-konsep tandingan yang tidak didapatkan dalam berbagai kitab tersebut. Ketiga, performen Gus Kahar baik saat pengajian, di rumah, maupun di berbagai tempat

\footnotetext{
${ }^{42}$ Berbagai karya tasawuf yang tidak banyak dikaji atau menjadi kurikulum pesantren sekalipun dikupas Gus Kahar tanpa pernah membaca. Para murid yang menyimak terheran-heran. Sebab, selesai Gus Kahar mengupas inti-inti dari berbagai kitab dimaksud, para murid membaca uraian di dalam kitab seperti penjelasan Gus Kahar. Di antara kitab klasik tasawuf karya guru besar kaum sufi adalah (1) al-Insān al-Kämil, karya al-Jìlī, (2) Fușuss al-Hikeam karya Ibn 'Arabī, (3) Sirr al-Asrār karya al-Jīlānī, dan masih banyak lagi karya tasawuf klasik lainnya. Diramu dari beberapa pengajian Majelis Shalawat Muhammad yang diikuti peneliti antara Agustus hingga Oktober 2015.
} 
lainnya selalu tampil apa adanya tanpa dibuat-buat. Keempat, antara tindakan dan ucapan Gus Kahar selalu sinkron. Bahkan Gus Kahar selalu meyakinkan kepada para pengikutnya, apapun yang diucapkan oleh Gus Kahar dalam seluruh pengajian didasarkan pada apa yang dilihat dan dikerjakan secara nyata.

\section{Continuity and Change dan Transmisi Shalawat Muhammad}

Pemikiran sufisme Gus Kahar dalam Majelis Shalawat Muhammad memiliki kesinambungan dengan ajaran sufisme sebelumnya, baik sufisme di Indonesia maupun sufisme di kawasan Timur Tengah. Di berbagai Majelis Shalawat Muhammad, Gus Kahar selalu menekankan bahwa pemikiran para guru sufi besar era Islam klasik maupun para guru sufi di Indonesia dari generasi para Wali Sanga (abad ke-15 hingga 16) maupun generasi sesudahnya, terus berkesinambungan hingga para guru sufi era 1980-an. Namun demikian, ajaran Gus Kahar selalu disesuaikan dengan dinamika kehidupan para jemaah masa kini. Dengan kata lain, prinsip-prinsip kesinambungan (continuity) ajaran sufisme sebelumnya dengan perubahan (change) kehidupan masyarakat modern selalu berjalan seirama.

Prinsip conitinuity and change ini mencakup doktrin ajaran yang dibawa oleh masing-masing tokoh dari generasi Rasulullah, sahabat, täbi în (para guru sufi besar), hingga para ulama di Indonesia yang menyandang gelar wali Allah. Proses terjadinya transfer of knowledge berlangsung setelah seseorang mampu (dalam istilah Gus Kahar) meluluskan dan meloloskan diri di bawah bimbingan rohani seorang guru tasawuf. Proses transfer or knowledge dalam dunia tasawuf dikenal dengan mukäshafah yang berujung pada hadirnya ilmu ladunni pada diri seseorang tersebut. Prinsip continuity (kesinambungan) inilah menempatkan ajaran Islam secara genuine ada pada ajaran dan doktrin tasawuf.

Makna change atau perubahan dalam dimensi ajaran sufisme yang dibawa oleh para tokoh sufi di setiap era adalah penyempurnaan doktrin pokok ajaran tasawuf dari generasi sebelumnya. Prinsip penyempurnaan disesuaikan dengan dinamika kehidupan masyarakat, baik dari aspek geografis (place) maupun masa atau zaman (time) yang selalu berubah. Tasawuf dengan ruh tauhid memiliki tanggung jawab dalam mengawal berbagai proses perubahan. Setiap tokoh sufi di eranya, memiliki tanggungjawab spiritual dalam mengawal setiap 
proses perubahan dengan menghadirkan doktrin tasawuf untuk diajarkan kepada publik luas. Gus Kahar mengatakan sembari menukil salah satu hadith yang jarang dinukil, "Umat Rasulullah di akhir zaman akan lebih baik dari pada umat-umat sebelumnya." ${ }^{43}$ Tafsir Gus Kahar ini didasarkan atas dialog antara Nabi Musa dengan Allah yang tertuang dalam kitab Taurat. ${ }^{44}$

Eksistensi para sufi dari masa ke masa dalam arti sebenarnya adalah menyempurnakan essensi spritualitas Islam disesuaikan realitas zaman masing-masing. Setidaknya, masing-masing tokoh itu menjelaskan ulang pokok-pokok spiritualitas Islam yang diajarkan oleh Nabi Muhammad, para sahabat, tābi'īn, dan seterusnya. Lahirnya beragamam kitab-kitab tasawuf bertujuan menjelaskan doktrin pokok yang pernah diajarkan Nabi Muhammad dan para sahabat. Dua periode ini merupakan sumber primer doktrin spiritualitas Islam. Tetapi, pada dua periode ini ajaran-ajaran tersebut bersifat doktrin pokok dan belum ditulis secara panjang lebar. Tradisi ilmiah yang telah berkembang saat itu masih terbatas pada tradisi "tutur" yang dikenal dengan istilah hadīth nabi dan athär para sahabat. ${ }^{45}$

${ }^{43}$ Gus Kahar, Wawancara, Sidoarjo 11 September 2015.

${ }^{44}$ Di dalam dialog tersebut, Nabi Musa bertanya kepada Allah tentang adakah umat yang lebih baik dari umatnya. Diriwayatkan oleh Abū Nu'aym dari Abū Hurayrah, Rasulullah bersabda: "Bahwa ketika Nabi Musa diberi kitab Taurat, maka di dalamnya ia menemukan kabar tentang umat ini (baca: Umat Muhammad), lalu Nabi Musa bertanya kepada Allah, Ya Tuhanku aku menemukan dalam lembaranlembaran Taurat berita tentang umat yang paling akhir dan paling terdepan, maka jadikanlah mereka sebagai umatku. Allah menjawab, mereka adalah umat Muhammad. Nabi Musa berkata, "Aku menemukan dalam lembaran Taurat, umat yang kitab sucinya berada dalam hati mereka, sementara mereka membacanya. Jadikanlah mereka umatku." Allah berfirman: "Mereka adalah umat Muhammad." Nabi Musa berkata, "Ya Allah, aku menemukan dalam lembaran Taurat, umat yang dihalalkan makan harta rampasan, jadikanlah mereka umatku." Allah berfirman: "Mereka adalah umat Muhammad." Nabi Musa berkata, "Ya Allah aku menemukan dalam lembaran Taurat, umat yang menjadikan sedekah dalam perut mereka, sementara mereka mendapatkan pahala, jadikanlah mereka umatku." Allah berfirman: "Mereka adalah umat Muhammad". Nabi Musa berkata: "Ya Allah, jadikan aku sebagai umat Muhammad. Jika demikian, maka aku telah diberi dua perkara." Allah berfirman: "Wahai Musa, sesungguhnya, aku telah memilihmu di atas manusia dengan Risalah dan Kalam Ku. Maka ambillah apa yang telah aku beri dan jadilah engkau dari golongan orang-orang yang bersyukur". Nabi Musa berkata, "Aku rida wahai Tuhanku". Lihat Ibn Kathīr, Tarbīb wa Tahdhīb al-Kitāb al-Bidāyah wa al-Nihāyah (Riyad: Dār al-Wațan, 2002).

${ }^{45}$ Hadīth dimaksud seperti penjelasan banyak ulama meliputi perkataan, perbuatan, dan sifat Nabi Muhammad. Begitu pula pengertian yang sama juga dimaksud pada 
Berdasarkan atas sumber primer pada dua periode ini menjadi basis pijakan selanjutnya bagi doktrin ajaran sufi yang dikembangkan serta disesuaikan dinamika sosial masyarakat Muslim pada zaman masing-masing. 'Abd al-Qādir al-Jīlānī (470 H/1077 M- 561 H/1166 M) misalnya, menjabarkan secara panjang lebar ajaran-ajaran pokok Rasulullah dan para sahabat di dalam banyak karyanya. Al-Jīlānī, seperti termaktub dalam karyanya Sirr al-Asrär misalnya, selain menjelaskan tentang tangga-tangga spiritualitas Islam juga menulis tidak kurang dari 40 karya. $^{46}$ Karya tasawuf al-Jīlānī mencakup pemikiran sangat luas dan mendalam mengenai seluk beluk pemikiran tasawuf. Dalam karya Sirr al-Asrār sebagai salah satu karya magnum opus, al-Jîlānī merumuskan beberapa konsep kunci seperti; hati (qalb), hati intuitif (fu'a d), jiwa (rüh), dan lubuk hati yang paling dalam (lubb) dalam memahami rahasia alam semesta, dan eksistensi Tuhan (Allah). Kata kunci di dalam karya ini adalah terbuka dimensi metafisis hubungan antara manusia dengan Allah yang disebut futūh al-ghayb. ${ }^{47}$ Hampir sama dengan karya ini, terdapat karya al-Jīlānī lainnya, yakni Fatḥ al-Rabbanni wa al-Fayd al-Rahmānī. ${ }^{48}$ Pokok-pokok doktrin di dalam karya ini lebih banyak menjelaskan tentang pembersihan hati agar bisa sampai makrifat Allah. Karya al-Jīlān̄̄ yang luas dan mendalam ini disederhanakan dalam doktrin yang dikemudian hari melembaga dalam institusi tarekat, yakni tarekat Qādirīyah.

Al-Jîlānī berbeda dengan 'Abd al-Karīm b. Ibrāhīm al-Jìlī (767 $\mathrm{H} / 1365 \mathrm{M}-832 \mathrm{H} / 1428 \mathrm{M}$ ), yang lebih dikenal dengan nama al-jīlí. Meskipun tidak melembagakan ajaran tasawufnya ke dalam institusi tarekat, tetapi, al-jilī menyempurnakan ajaran-ajaran al-j̄ilānī. Diketahui bahwa al-Jîlī menjadi pengikut al-Jīlānī. Meskipun tidak hidup sezaman dengan al-Jīlān $\overline{1}$, al-Jîl $\overline{1}$ memiliki hubungan darah dengan al-Jîlānī. Al-Jìlī terlahir dari salah seorang putri al-Jîlānī. ${ }^{49}$ Karena memiliki garis geneologi darah keturunan ini, al-Jili memahami dengan baik terhadap spektrum luas pemikiran al-Jīlānī yang tidak lain

makna athar, yaitu mencakup perkataan, perbuatan, dan sifat-sifat para sahabat Rasulullah yang terpilih dan dekat dengan Rasulullah.

46 'Abd al-Qādir al-Jīlānī, Sirr al-Asrār wa Madār al-Anwàr (Lebanon: Dār al-Kutub al'Ilmìyah, 2010).

${ }^{47}$ Ibid., 65-175.

48 'Abd al-Qādir al-Jīlānī, Fatḥ al-Rabbānì wa al-Faỵ̣ al-Raḥmānì (Lebanon: Dār alKutub al-'Ilmīyah, 2010).

49 'Abd al-Karīm b. Ibrāhīm al-Jìlī, al-Insān al-Kāmil (Lebanon: Dār al-Kutub al'Ilmīyah, 2010), 7. 
adalah kakek al-Jilī. Sesuai dengan prinsip continuity and change, al-Jìli menyempurnakan berbagai pemikiran sang kakek disesuaikan dengan perkembangan zaman dan dinamika kehidupan sosial, politik, dan budaya masyarakat. Cakrawala yang dalam dan luas tentang pemikiran al-jīli tertuang dalam karya-karyanya tidak kurang dari 30 kitab tasawuf. Di antara karya al-Jîlī sebagai master piece adalah karyanya yang berjudul al-Insān al-Kämil. ${ }^{50}$

Pemikiran sufisme al-jîlī dapat dipahami meneruskan tradisi pemikiran para tokoh tasawuf sebelumnya, selain meneruskan dan menyempurnakan pemikiran kakeknya, al-Jîlānī juga tokoh seperti Manșūr al-Hallāj (244 H/858 M-309 H/913 M), al-Shiblī (247 H/861 M-334 M/964 M), dan Ibn 'Arabī (560 H/1165 M-638 M/1240 M). Nama al-Hallāj dan Ibn 'Arabī dikenal memiliki pemikiran tasawuf yang dianggap kontroversi di kalangan masyarakat umum. Al-Ḥallāj masyhur dengan pemikiran tasawuf ḩulūl. Sedangkan Ibn 'Arabī dengan konsep wahdat al-wujüd.

Pemikiran tasawuf al-Ḥallāj, Ibn 'Arabī, al-Shiblī, al-Jīlānī, maupun al-Jìli dalam perkembangan tasawuf memberi banyak pengaruh di belahan dunia Muslim, tidak terkecuali di Indonesia. Semenjak abad ke-15 dan selanjutnya, pengaruh pemikiran tokoh-tokoh tasawuf di atas terus mewarnai, baik tradisi pemikiran maupun praksis kehidupan tasawuf di nusantara. Pada abad ke-15 yang identik dengan era Walisongo, khususnya di Jawa, terdapat nama tokoh Abdul Jalil atau populer dengan nama Siti Jenar dikenal mewarisi doktrin ḅulül atau ittiḩād al-Ḥallāj maupun waḥdat al-wujūd Ibn 'Arabī. Abad ke-17 di Sumatera lahir seorang tokoh tasawuf, yakni Hamzah Fansuri yang juga dikenal menganut ajaran para sufi di atas. ${ }^{51}$ Konsep Nür Muhammad Ibn 'Arabī cukup mendominasi dalam pemikiran Fansuri. Hal yang sama dalam karya al-Insān al-Kämil al-jìlī juga memberi warna tersendiri bagi banyak karya Fansuri. ${ }^{52}$ Pada abad ke-18 dan 19, pemikiran tokoh tasawuf disebut di atas secara berkelanjutan juga

\footnotetext{
${ }^{50}$ Pada bagian akhir kitab al-Insān al-Kämil, al-Jīlì mengisahkan tentang maqām alShiblī pada saat mencapai maqām tajalli. Di hadapan para muridnya yang telah mencapai maqām kashf, al-Shiblī berkata: Wa qäla al-Shiblì li tilmidhih: ashbadu inni Rasül Allah, wa kāna al-tilmïdh sạhịib kashffa'arafah. Faqäla: Ashbad Annaka Rasūl Allah. Al-Jìlī, al-Insān al-Kämil, 277.

51 Mira Fauziah, "Pemikiran Tasawuf Hamzah Fansuri", Jurnal Substansia, Vol. 15, No. 2 (2013).

52 Ibid., 299.
} 
menyebar hingga di daerah Kalimantan. Di Banjar, terdapat nama seorang sufi yang menganut ajaran al-Hallāj. Tokoh tersebut adalah Abdul Hamid Abulung. ${ }^{53}$

Transmisi pemikiran sufisme dari tokoh-tokoh sufi besar di Timur Tengah dengan pasang surutnya datang dan pergi di berbagai daerah di Indonesia. Jawa Timur yang sejak abad ke-15 menjadi salah satu pusat keislaman penting di Indonesia juga mengalami proses berkesinambungan dan perubahan. Selain nama al-Jīlān̄̄ sebagai sumber utama ajaran tarekat Qadiriyah, terdapat nama-nama sufi besar seperti Abū Hasan al-Shādhilī (1197 M-1258 M) juga melembaga menjadi institusi tarekat, yakni tarekat Shādhilīyah. Begitu juga dengan sekian banyak nama tarekat lain, baik yang tergabung dalam wadah Jamiyyah Ahli Tarekat an-Nahdliyah maupun di luar jam'ỹah ini. Selain pengaruh para tokoh sufi dengan wadah lembaga tarekat juga para sufi besar seperti disebutkan sebelumnya juga memiliki pengaruh yang tidak kecil di Jawa Timur. Bahkan, terdapat nama ulama asli Jawa Timur dari Kedunglo Kediri, yakni KH. Abdul Madjid, mendirikan tarekat yang berdiri sendiri dengan nama tarekat Wahidiyah. ${ }^{54}$ Berbeda dengan kiai lainnya, tarekat Wahidiyah Kiai Madjid tidak memiliki afiliasi secara langsung dengan tarekat lainnya di Timur Tengah.

Fenomena KH. Madjid tidak ada bedanya dengan tokoh yang menjadi topik utama riset ini. Nama Gus Kahar pada awalnya tidak pernah menjadi diskusi publik. Sejak awal 2000-an, nama Gus Kahar banyak menjadi perbincangan di kalangan dunia pesantren, kiai, dan kelas menengah Muslim perkotaan di Surabaya dan sekitarnya. Nama Shalawat yang disebarluaskan juga relatif kurang populer di kalangan banyak kiai, lebih-lebih di kalangan kelas menengah Muslim perkotaan. Lahirnya Shalawat Muhammad tidak ubahnya seperti

${ }^{53}$ Dalam versi masyarakat Banjar, tokoh Abdul Hamid akhirnya dieksekusi oleh Kesultanan Banjar atas fatwa Arsyad al-Banjari. Lihat Mujibburrahman, "Tasawuf di Banjar: Kesinambungan dan Perubahan Tradisi Keagamaan”, Kanz Philoshopia, Vol. 3, No. 2 (2013), 158-159.

${ }^{54}$ Kiai Abdul Madjid adalah putra seorang ulama karismatik asal Kedunglo Kediri, yakni Kiai Makruf. Keduanya diyakini secara luas di kalangan masyarakat sebagai kiai yang memiliki maqām kewalian. Kiai Madjid (begitu masyarakat memanggilnya), sebelum berubah menjadi tarekat, awalnya adalah majelis Shalawat Wahidiyah. Lambat laun majelis Shalawat Wahidiyah ini berubah menjadi institusi tarekat Wahidiyah. Beberapa ajaran Kiai Madjid sempat mengundang polemik. Kiai Machrus Ali Lirboyo Kediri, tercatat sebagai salah seorang kiai yang banyak menentang berbagai ajaran Kiai Madjid ini. 
Shalawat Wahidiyah yang diajarkan oleh Gus Madjid. Shalawat Wahidiyah di kalangan kebanyakan kiai juga kurang populer. Baik Shalawat Wahidiyah maupun Shalawat Muhammad, sebelum disebarluaskan kedua tokoh ini, sebelumnya tidak pernah diajarkan dan diamalkan, baik di lingkungan kebanyakan kiai, lebih-lebih kelas menengah Muslim perkotaan.

Gus Kahar menjelaskan, ajaran Shalawat Muhammad memiliki sanad atau transmisi yang jelas. Gus Kahar mendapat ajaran Shalawat Muhammad dari para guru-guru sufi di Indonesia secara berkesinambungan hingga para guru-guru sufi seperti al-Jīlanī, alShiblī, Ibn 'Arabī, al-Jillī, al-Ḥallāj, Ḥasan al-Shādhilī, terus hingga Hasan al-Bașrī, empat sahabat Rasulullah, dan berakhir hingga Rasulullah. Sebelum menyebarkan ajaran Shalawat Muhammad, Gus Kahar terlebih dahulu mentaskhihkan kepada kiai-kiai sepuh dari tahun 1980-an hingga1990-an. Gus Kahar keliling untuk mentashihkan bait-bait Shalawat Muhammad kepada simpul-simpul kiai yang di mata publik dikenal dengan maqām kewalian di Jawa. "Saya sudah mentashihkan bait-bait Shalawat Muhammad ini kepada para kiai sepuh," tegasnya..$^{55}$ Beberapa simpul kiai sepuh dimaksud antara lain adalah KH. Abdul Hamid Pasuruan, KH. Abdul Ghoni Rangkah Surabaya, Habib Masrur Bafaqih Curah Malang, KH. Kusnan Tumpang Malang, Abah Toyyib Kemayoran Surabaya, Abah Toyyib Semengko Mojokerto, Mbah Hamid Kajoran Magelang, KH. Dalhar Magelang, KH. Dimyati Banten, dan masih banyak lagi.

Autentisitas bait-bait Shalawat Muhammad dijumpai salah satunya dalam kitab Nūr al-Burhān, karya KH. Hanif Muslih Mranggen Jawa Tengah. ${ }^{56}$ Di dalam kitab Nür al-Burbān, jilid I, dijelaskan tentang keutamaan (mariyab) Shalawat Muhammad serta penjelasan autentisitas amalan Shalawat Muhammad. Selain itu, dalam kitab tersebut juga dijelaskan, bahwa selain Rasulullah, para sahabat dan para sufi-sufi besar secara simultan dan berkesinambungan hingga ulama tertentu di Indonesia juga mengamalkan bait-bait Shalawat Muhammad ini. Menurut Gus Kahar, ajaran Shalawat Muhammad selama ratusan tahun hanya diamalkan oleh guru atau ulama sufi

${ }^{55}$ Gus Kahar, Wawancara, Sidoarjo 11 September 2015.

56 Di dalam kitab Nūr al-Burbān, KH. Muslih menyebutkan, bahwa salah satu pembawa (sanad) ajaran Shalawat Muhammad tidak lain adalah 'Abd al-Qādir alJīlanī. KH. Muslih banyak meriwayatkan mazìyah (keutamaan) Shalawat Muhammad, selain mengambil pernyataan dari al-Jīlān̄i juga Sofyan al-Syauri. Lihat KH. Hanif Muslih, Nur al-Burbān jilid I (Semarang: Karya Thoha Putra 1382 H), 104-108. 
tertentu yang sifatnya rahasia/sirr. Gus Kahar meyakinkan, bahwa Shalawat Muhammad dahulunya menjadi amalan para guru-guru tarekat. Hanya saja bait-bait Shalawat Muhammad tidak pernah ditulis atau dipublikasikan secara massal untuk diajarkan kepada publik secara luas. "Dulu, para guru tarekat pasti mengamalkan bait-bait Shalawat Muhammad," tandas Gus Kahar. ${ }^{57}$ Pernyataan Gus Kahar dapat dibenarkan seperti tertulis dalam kitab Nür al-Burhān di atas. KH. Muslih sebagai penulis kitab dimaksud tidak lain adalah seorang guru atau murshid Tarekat Qādirīyah wa Naqshabandīyah (TQN) di Mranggen Jawa Tengah.

Suatu fakta, selain ajaran Shalawat Muhammad tidak banyak diketahui oleh sebagian besar umat Islam selama ratusan tahun, Shalawat Muhammad hanya diamalkan secara amat terbatas oleh para individu kiai yang menyandang gelar guru atau murshid tarekat. Gus Kahar mengakui, bahwa, sebagian besar perjalanan hidupnya dalam menjalani mujähadah, sälik-sulük, serta riyädah, hanya menegakkan dan menjalankan bait-bait yang terkandung dalam Shalawat Muhammad. Gus Kahar mendapat amanat para guru sufi untuk menyebarluaskan ajaran Shalawat Muhammad tidak lagi secara terbatas, tetapi untuk masyarakat luas. "Kalau dunyo iki wes rusak, sebarno (kalau dunia sudah rusak, maka sebarkan) ajaran Shalawat Muhammad," kenang Gus Kahar menirukan amanat para guru-guru sufinya. ${ }^{58}$

Gus Kahar menegaskan, transmisi ajaran Shalawat Muhammad yang diajarkannya memiliki sanad yang tidak pernah terputus hingga Rasulullah. "Dahulu, para murshid tarekat Qādirīyah wa Naqshabandìah mengamalkan Shalawat Muhammad. Bahkan, Shalawat Muhammad sebenarnya menjadi rangkaian dari zikir Qādirīyah wa Naqshabandīyah. Namun Shalawat Muhammad ini hanya diajarkan untuk orang-orang tertentu secara sirr," tegas Gus Kahar. ${ }^{59}$ Dalam pandangannya, selain merujuk Raden Rahmat atau Sunan Ampel, sebagai pengamal Shalawat sekaligus transmiter, terdapat tokoh sentral di Jawa Timur yang memiliki pengaruh paling besar di abad ke20, yakni KH. Kholil Bangkalan. Gus Kahar membuka tabir secara spiritual mengenai Kiai Kholil ini. Menurutnya, selain pengamal Shalawat Muhammad, sosok Kiai Kholil adalah murshid dari berbagai tarekat yang berkembang luas di Indonesia.

\footnotetext{
${ }^{57}$ Gus Kahar, Wawancara, Sidoarjo 11 September 2015.

${ }^{58}$ Gus Kahar, Wawancara, Sidoarjo 17 September 2015.

${ }^{59}$ Ibid.
} 


\section{Penutup}

Di tengah kegairahan spiritual masyarakat kelas menengah perkotaan lahir suatu majelis yang bernama Majelis Shalawat Muhammad. Majelis sejenis juga lahir di kota-kota besar di Indonesia. Di luar Majelis Shalawat Muhammad telah dikenal dengan menjamurnya majelis zikir. Para pengikutnya jelas-jelas menunjukkan kelas menengah perkotaan. Menariknya, sebagian majelis ini diikuti oleh kelas menengah perkotaan yang dilahirkan dari tradisi pemikiran neomodernis yang dahulunya menentang ajaran sufisme. Kelompok ini, oleh Howell, disebutnya sebagai fenomena urban sufism.

Lahir dan berkembangnya Majelis Shalawat Muhammad selain memberi warna baru bagi dinamika urban sufism. Seolah hal ini juga menyadarkan kembali akan makna urban sufism maupun sufism itu sendiri. Dilihat dari dimensi kesejarahan, lahirnya urban sufism dalam Majelis Shalawat Muhammad sepertinya meneguhkan kembali suatu konsep sufism secara generik. Bahwa tradisi sufisme tidak bisa terlepas dari akar-akarnya, yakni transmisi pengetahuan berbasis praktik ('amaliyab) di bawah bimbingan seorang guru (murshid) secara ketat, rigid, dan terstruktur. Praktik pendidikan ini dalam konsep sufisme dikenal dengan istilah sälik, sulük, riyädah, mujähadah, dan seterusnya. Dengan kata lain, prinsip continuity menjadi prasyarat mutlak dalam tradisi sufisme itu sendiri.

Berbasis pada prinsip continuity ini melahirkan doktrin sufisme yang secara generik memiliki benang merah dengan ajaran sufisme dari guru-guru sufi di era sebelumnya. Suatu yang membedakan hanya perbedaan dimensi ruang dan waktu. Perbedaan dimensi ini melahirkan kreativitas ajaran seorang guru sufi sesuai prinsip perubahan (change) itu sendiri menurut logika (budaya dan tradisi) masyarakat di suatu era dan tempat, baik ajaran maupun perilaku yang dipersonifikasikan oleh Gus Kahar dalam Majelis Shalawat Muhammad menggambarkan prinsip tersebut. Di satu sisi, sosok Gus Kahar meskipun tidak pernah mengenyam pendidikan formal maupun pesantren, tetapi, cakrawala pemikiran tentang tauhid maupun hakikat seperti tanpa batas. Di sisi lain, Gus Kahar yang hidup di tengah-tengah muridnya yang merepresentasikan kelas menengah perkotaan dan hidup di kota besar seperti Surabaya juga hidup secara modern. Realitas inilah menunjukkan warna lain tentang dinamika perubahan (change) dalam ajaran sufisme. 


\section{Daftar Rujukan}

A'la, Abd. "Geneaologi Radikalisme Muslim Nusantara: Akar dan Karakteristik Pemikiran dan Gerakan Kaum Paderi dalam Perspektif Hubungan Agama dan Politik Kekuasaan", Pidato Ilmiah Pengukuhan Guru Besar dalam Bidang Ilmu Sejarah Pemikiran Politik Islam, IAIN Sunan Ampel Surabaya, 2008.

Amin, Saiful. Wawancara. Surabaya 18 September 2015.

Azra, Azyumardi. Jaringan Ulama Timur Tengah dan Kepulauan Nusantara Abad XVII dan XVIII. Bandung: Mizan, 1994.

Baban, Muhammad. al-Majmū'ah al-Mubārakah fì Salawät al-Ma'thürah wa al-A'mäl al-Mabrürah. t.t.: t.tp., t.th.

Fathurahman, Oman. "Urban Sufism: Perubahan dan Kesinambungan Ajaran Tasawuf", dalam Rizal Sukma dan Clara Joewono (eds.), Gerakan dan Pemikiran Islam Indonesia Kontemporer. Jakarta: CSIS, 2007.

Fauziah, Mira. "Pemikiran Tasawuf Hamzah Fansuri”, Jurnal Substansia, Vol. 15, No. 2, 2013.

Howell, Julia D. "Modernity and Islamic Spirituality in Indonesia's New Sufi Networks," dalam Martin van Bruinessen dan Julia D. Howell (eds.), Sufism and The Modern in Islam. New York and London: IB Tauris, 2007.

----. "Repackaging Sufism in Urban Indonesia", ISIM Review, Vol. 19/Spring, 2007.

-----. "Sufism and The Indonesian Islamic Revival", The Journal of Asian Studies, Vol. 60, No. 3, 2001.

Jìlānī (al), 'Abd al-Qādir. Fatḥ al-Rabbānì wa al-Fayd al-Raḅmānì (Lebanon: Dār al-Kutub al-'Ilmìyah, 2010.

-----. Sirr al-Asrār wa Madār al-Anwār. Lebanon: Dār al-Kutub al'Ilmìyah, 2010.

Jìlì (al), 'Abd al-Karīm b. Ibrāhīm. al-Insān al-Kāmil. Lebanon: Dār alKutub al-'Ilmìnah, 2010.

Jodi (Manager Cafe Rollas Tunjungan Plaza (TP) Surabaya). Wawancara. Surabaya 18 September 2015.

Kahar, Gus. Dhiker al-Mubärak Shaykhunā Kahar. t.t.: t.tp., 2014.

----. Kitab Shalawat Muhammad Rahmatan li al-'Alamin. t.t.: t.tp., 2010.

----. Wawancara. Sidoarjo 11 September 2015.

----. Wawancara. Sidoarjo 9 September 2015.

----. Wawancara. Sidoarjo 17 September 2015. 
Kathīr, Ibn. Tarbìb wa Tahdhìb al-Kitāb al-Bidāyah wa al-Nihāyah. Riyad: Dār al-Watan, 2002.

Madjid, Nurcholis. "Tasawuf sebagai Inti Keberagamaan", Jurnal Pesantren, Vol. 2, No. 3, 1985.

Millie, Julian., Barton, Greg., Hindasah, Linda., and Moriyama, Mikihiro. "Post-Authoritarian Diversity in Indonesia's StateOwned Mosques: A Manakiban Case Study", Journal of Southeast Asian Studies, Vol. 45, No. 2, 2014.

Muhammad. Wawancara. Surabaya 18 September 2015.

Muis, Gusti Abdul. "Menyimak Tasawuf Sunni”, Jurnal Pesantren, Vol. 2, No. 3, 1985.

Mujibburrahman. "Tasawuf di Banjar: Kesinambungan dan Perubahan Tradisi Keagamaan", Kan₹ Philoshopia, Vol. 3, No. 2, 2013.

Muslih, KH. Hanif. Nur al-Burbān jilid I. Semarang: Karya Thoha Putra $1382 \mathrm{H}$.

Rojak, Abdul. Wawancara. Surabaya 18 September 2015.

Ross, Eric. Sufi City: Urban Design and Archetypes in Touba. Rochester: University of Rochester Press, 2006.

Sururi, Muhammad. Wawancara. Surabaya 18 September 2015.

Zamhari, Arif dan Howell, Julia D. "Taking Sufism to The Streets: Majelis Zikir and Majelis Salawat as New Venues for Popular Islamic Piety in Indonesia", Review of Indonesian and Malaysian Affairs, Vol. 46, No. 2, 2013.

Zamhari, Arif. "Socio-Structural Innovations in Indonesia's Urban Sufism: The Case Study of Majelis Zikir and Shalawat Nurul Mustofa," Journal of Indonesian Islam, Vol. 7, No. 1, 2013. 